\title{
COMBINING APPROACHES TO SUPPORT HIGH NATURE VALUE FARMLAND IN SOUTHERN TRANSYLVANIA, ROMANIA
}

\author{
Laura SUTCLIFFE ${ }^{1,2 *}$, \\ John AKEROYD ${ }^{2}$, Nat PAGE ${ }^{2}$, Razvan POPA ${ }^{2}$
}

\begin{abstract}
The region of Târnava Mare in Southern Transylvania contains extensive semi-natural open landscapes maintained by predominantly low-intensity farming, which is widespread in Romania and indeed many areas of Eastern Europe. Threats to these species-rich habitats from agricultural intensification and land abandonment have been increasing in recent years, to a large extent linked with Romania's accession to the EU in 2007. At the same time, however, the opportunities for biodiversity conservation in the area have expanded. In 2008, the region became a Site of Community Importance (SCI) as part of the Natura 2000 network, and farmers have applied agri-environment schemes as part of the EU Common Agricultural Policy since 2006. Furthermore, the Târnava Mare region has been the location of several EU and nationally funded projects combining research, practical and information measures. In this article, we review these various instruments from the practical perspective of an NGO that has been working since 2004 to support High Nature Value farmland and rural communities in this region. We focus on three major support measures - agri-environment schemes, Natura 2000, and publicly funded conservation projects - and consider their effects individually and collectively. We conclude that the presence of multiple instruments can have synergistic effects on the conservation of semi-natural open habitats such as HNV farmland, and that this overlap provides a certain amount of resilience: if one instrument fails, another may fill the gap. Cross-cutting projects combining research with activities to tackle the "problem" of the socio-economic undesirability of low-intensity farming as well as the "symptom" of the loss of HNV farmland are also particularly important in this context.
\end{abstract}

Keywords: Common Agricultural Policy, Eastern Europe, farmland biodiversity, HNV, low-intensity agriculture, Natura 2000, nature conservation, NGO.

\section{Izvleček}

Na območju Târnava Mare v južni Transilvaniji najdemo ekstenzivno polnaravno odprto krajino, ki se ohranja predvsem z nizko intenzivnim kmetijstvom, ki je splošno razširjeno v Romuniji in številnih drugih območjih v vzhodni Evropi. Ogroženost teh vrstno bogatih habitatov se v zadnjih letih povečuje zaradi intenziviranja kmetijstva in opuščanja obdelovanja kar je v veliki meri povezano z vstopom Romunije v EU leta 2007. Obenem pa so se na tem območju povečale možnosti za ohranjanje biodiverzitete. V letu 2008 je regija postala območje pomembno za skupnost (SCI) kot del omrežja Natura 2000 in kmetje so se vključili v kmetijsko-okoljske sheme kot del skupne kmetijske politike EU od leta 2006. Dodatno so v regiji Târnava Mare izvajali številne evropske in nacionalne projekte $\mathrm{v}$ kombinaciji z znanstvenimi raziskavami, praktičnimi ukrepi in osveščanjem. $\mathrm{V}$ članku predstavljamo različne praktične inštrumente $\mathrm{z}$ vidika NVO, ki podpira kmetijstvo z visoko vrednostjo narave (HNV) od leta 2004 in podeželsko skupnost v tej regiji. Osredotočili smo se na tri glavne podporne ukrepe - kmetijsko-okoljske sheme, Naturo 2000 in javno financirane naravovarstvene projekte in preučili njihove posamične in skupen učinek. Zaključimo lahko, da imajo lahko številni inštrumenti sinergistične učinke na varstvo pol naravnih odprtih habitatov, kot je na primer kmetijstvo z visoko vrednostjo

${ }^{1}$ Department of Plant Ecology and Ecosystem Research, University of Göttingen, Untere Karspüle 2, 37073 Göttingen, Germany. E-mail: sutcliffe.laura@gmail.com

${ }^{2}$ Fundația ADEPT Transilvania, Str. Principala 166, Saschiz, Mures 547510, Romania. E-mail: jrakeroyd@gmail.com, nat(a)fundatia-adept.org, poparazvand@yahoo.com; URL: www.fundatia-adept.org

* Corresponding author: sutcliffe.laura@gmail.com 
narave (HNV). To prekrivanje ukrepov zagotavlja določeno odpornost, saj če en inštrument ni uspešen, ga lahko nadomesti drugi. Interdisciplinarni projekti, ki združujejo raziskave z dejavnostmi, ki rešujejo probleme socio-ekonomske nezaželenosti kmetovanja $\mathrm{z}$ nizko intenzivnostjo in zmanjševanja kmetovanja $\mathrm{z} \mathrm{z}$ visoko vrednostjo narave (HNV) so še posebej pomembni v tem okviru.

Ključne besede: Skupna kmetijska politika, Vzhodna Evropa, kmetijska biodiverziteta, HNV, kmetijstvo z nizko intenzivnostjo, Natura 2000, naravovarstvo, NVO.

\section{INTRODUCTION}

Farming has played a key role in the creation and maintenance of the vast majority of Europe's semi-natural open habitats, but has also in the last century contributed to their widespread destruction (Stoate et al. 2009). In this era of agricultural intensification and industrialisation, it is increasingly important to distinguish between the types of farmland that provide valuable habitats and ecosystem services, and those that are hostile environments for biodiversity and contribute to pollution and other damage to surrounding areas. This thinking led to the development of the concept of High Nature Value (HNV) farmland which denotes areas with a large proportion of semi-natural vegetation (type 1 ), with a mosaic of low intensity agriculture and natural and structural elements (type 2), or supporting rare species or a significant proportion of European or world populations (type 3) (Paracchini et al. 2008). HNV farmland, especially types 1 and 2, generally relies on farming practices that are low-intensity in terms of the chemical input and machinery, but often have high-intensity input of human labour. They are also frequently associated with a biodiversity/yield trade-off that leads to them struggling for existence in the modern European market economy (Plieninger \& Bieling 2013).

Comparatively little HNV farmland survives in Europe today, having been largely replaced by intensive agriculture or abandoned as unprofitable. It continues to face pressure from multiple sources, including subsidy support for intensification, expansion by agro-industry, falling market prices for products, productivist attitudes among farmers, and a declining labour force due to rural depopulation (see e.g. Oppermann et al. 2012). However, in recent years there has also been increasing recognition of the considerable provision of public goods and ecosystem services, such as very high levels of biodiversity, including genetic resources of fodder crop relatives and medicinal plants, but also carbon storage, recreation, support of pollinators, flood prevention and many other benefits (Paracchini \& Oppermann 2012). This has led to a growth in the number of instruments directly and indirectly supporting HNV farmland. These may be legislative (e.g. EU Birds and Habitats Directives) as well as financial (e.g. compensatory payments through the Common Agricultural Policy), national (e.g. national protected areas) or international (e.g. EU Natura 2000), and funded publicly (e.g. EU LIFE programme) or privately (e.g. through Corporate Social Responsibility). Whilst these instruments by no means cover all species-rich farmland in Europe, there are also areas that experience an overlap addressing different aspects of HNV farmland loss. However, the impacts of these instruments on target habitats and species are rarely systematically evaluated, and the evidence suggests that their effectiveness has been mixed (see e.g. Kleijn et al. 2006, Hochkirch et al. 2013). In particular, the complex positive and negative interactions between these instruments in their goal of supporting species and habitats are rarely, if ever, studied holistically. Particularly in Romania and other areas of Southeast Europe, local and national institutions are still adapting to the implementation of many of these instruments since their relatively recent accession to the EU, and feedback is essential to their improvement (Iojă et al. 2010, Wegener et al. 2011).

The climate, biogeography and long history of management of the Transylvanian Plateau in Romania have led to the development of highly species-rich farmland habitats (a world record for vascular plant diversity was recorded in grasslands here; Wilson et al. 2012). The region of Târnava Mare in Southern Transylvania contains around 85,000 ha of species-rich farmland and forest in the foothills of the Romanian Carpathians. Named after the river that forms its northern border, the area was designated a Site of Community Importance (SCI: a preliminary phase before being accepted as a full Special Area of Conservation) as part of the EU Natura 2000 network in 2008, in recognition of its outstanding value to nature conservation (Akeroyd \& Page 2011). The region has a relatively 
low population density (around 30 inhabitants/ $\mathrm{km}^{2}$ ), and a typical range of farm sizes for Romania (nationally, $90 \%$ of holdings are below 5 ha in size). Due to its predominance of smallholdings with low-intensity farming, the region supports large areas of High Nature Value Farmland mainly of type 1 (semi-natural vegetation, as is found for example in the large common pastures; Figure 1a) and type 2 (mosaics of semi-natural and cultivated land with small-scale features; Figure 1b). It is an important area of semi-natural grassland (Akeroyd \& Page 2011) and is the focus of multiple conservation measures. Farmland in the Târnava Mare region plays a large role in supporting numerous species and habitats of conservation interest (see Table 1 and the references within).

Table 1: Published examples of habitats and species on Annexes I and II of the EU Habitats Directive in the Târnava Mare SCI that benefit from extensive farming practices. Overall, approximately a third of the habitats and two thirds of the species listed in the annexes of the Habitats Directive and present in the area are reliant to some extent on HNV farmland (our calculation).

Tabela 1: Objavljeni primeri habitatnih tipov in vrst na Prilogi I in II Habitatne direktive v Târnava Mare SCI, ki so zaradi ekstenzivnega kmetovanja v ugodnem stanju. Približno tretjina habitatnih tipov in dve tretjini vrst iz prilog Habitatne direktive je do neke mere odvisnih od HNV kmetovanja (naši izračuni).

\begin{tabular}{|c|c|c|}
\hline Code & Scientific (common) name & Relation to farmland and reference \\
\hline \multicolumn{3}{|c|}{ Amphibians } \\
\hline 1193 & Bombina variegata (Yellow-bellied toad) & Frequently use temporary ponds created by livestock or extensive \\
\hline 1166 & Triturus cristatus (Great crested newt) & farming activity: Scheele et al. (2014), Hartel et al. (2010a), \\
\hline 4008 & Triturus vulgaris ampelensis (Smooth newt) & Hartel et al. (2010b) \\
\hline \multicolumn{3}{|c|}{ Insects } \\
\hline 1088 & Cerambyx cerdo (Great capricorn beetle) & Abundant in veteran trees in wood-pastures: Hartel \& Moga (2010) \\
\hline 1074 & Eriogaster catax (Eastern Eggar) & $\begin{array}{l}\text { The caterpillars live on bushes common in pastures } \\
\text { in the region: Rákosy (2012) }\end{array}$ \\
\hline 1065 & Euphydryas aurinia (Marsh fritillary) & Occurs in a range of grassland types: Loos et al. (2014) \\
\hline 1060 & Lycaena dispar (Large copper) & Occurs in a range of grassland types: Loos et al. (2014) \\
\hline 1059 & Phengaris teleius (Scarce large blue) & Species of semi-natural grasslands: Schmitt \& Rákosy (2007) \\
\hline 1084 & Osmoderma eremita (Hermit beetle) & $\begin{array}{l}\text { Develops in hollow trees, which are frequent in wood-pastures: } \\
\text { Hartel \& Moga (2010) }\end{array}$ \\
\hline
\end{tabular}

Mammals
$1354 \quad$ Ursus arctos (Brown bear)

Forages in extensively grazed wood pastures for fruit and ant larvae: Roellig et al. (2014)

\begin{tabular}{|c|c|c|}
\hline \multicolumn{3}{|c|}{ Plants } \\
\hline 4068 & Adenophora liliifolia (Ladybells) & $\begin{array}{l}\text { Grows in damp meadows and on grazed movile (small hills): Speta \& } \\
\text { Rákosy (2010), Akeroyd et al. (2013) }\end{array}$ \\
\hline 4091 & Crambe tataria (Tartar cabbage) & $\begin{array}{l}\text { Grows in dry, eroded grasslands and grazed movile: Speta \& Rákosy } \\
\qquad(2010) \text {, Akeroyd et al. (2013) }\end{array}$ \\
\hline 1902 & $\begin{array}{c}\text { Cypripedium calceolus (Lady`s-slipper } \\
\text { orchid) }\end{array}$ & Grows in semi-shade, e.g. in wood-pastures: Öllerer (2012) \\
\hline 4067 & Echium russicum (Red Viper's-bugloss) & Species of dry grasslands: Speta \& Rákosy (2010), Akeroyd et al. (2013) \\
\hline 4097 & Iris aphylla subsp. Hungarica & $\begin{array}{l}\text { Species of dry meadows, scrub and movile : Speta \& Rákosy (2010), } \\
\text { Akeroyd et al. (2013) }\end{array}$ \\
\hline \multicolumn{3}{|c|}{ Habitat types } \\
\hline $40 \mathrm{~A} 0$ & Subcontinental peri-Pannonic scrub & \multirow{5}{*}{$\begin{array}{l}\text { Maintained by low-intensity grazing and mowing: } \\
\text { Akeroyd \& Bădărău (2012), Page et al. (2012) }\end{array}$} \\
\hline $6210^{*}$ & $\begin{array}{l}\text { Semi-natural dry grasslands and scrubland } \\
\text { facies on calcareous substrates (Festuco- } \\
\text { Brometalia) }(* \text { important orchid sites) }\end{array}$ & \\
\hline $6240 *$ & Sub-Pannonic steppic grasslands & \\
\hline 6430 & $\begin{array}{l}\text { Hydrophilous tall herb fringe communities } \\
\text { of plains and of the montane to alpine levels }\end{array}$ & \\
\hline 6510 & $\begin{array}{l}\text { Lowland hay meadows (Alopecurus } \\
\text { pratensis, Sanguisorba officinalis) }\end{array}$ & \\
\hline
\end{tabular}



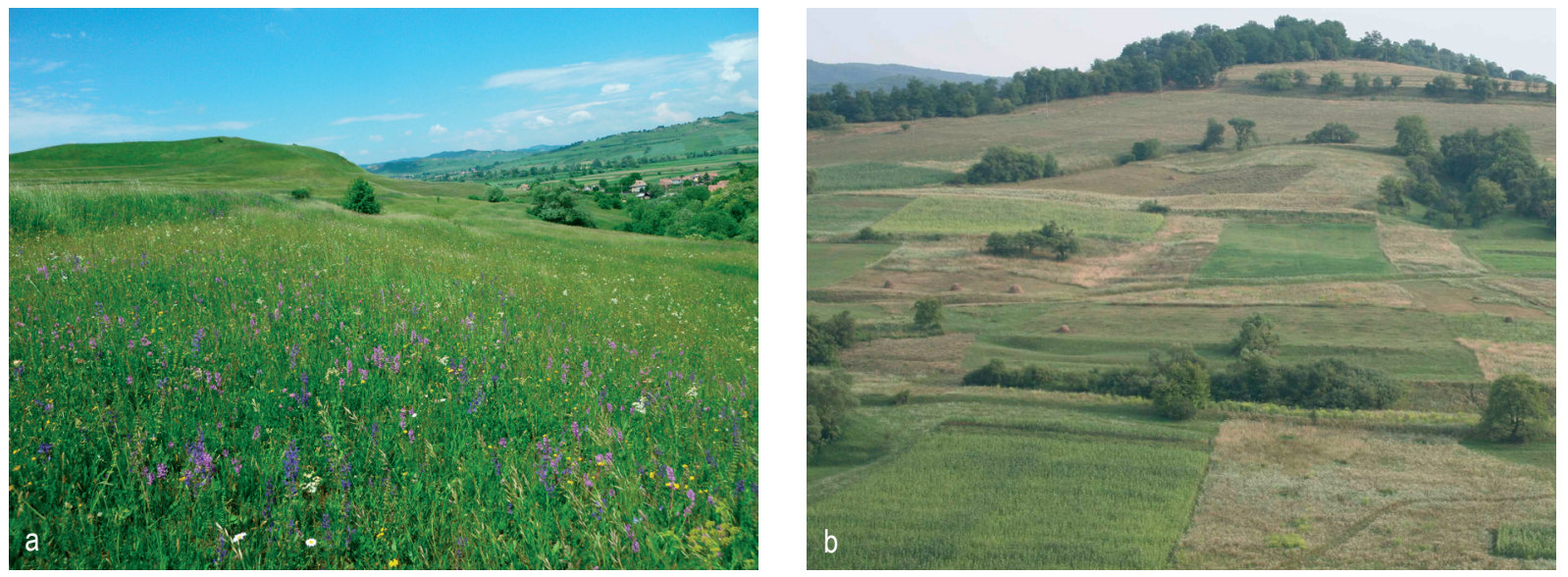

Figure 1: Typical farmed landscapes in the Târnava Mare region a) large-scale semi-natural grasslands (type 1 HNV), b) mosaic of low-intensity farmland habitats (type $2 \mathrm{HNV}$ ).

Slika 1: Značilna kmetijska krajina v regiji Târnava Mare a) velike površine pol naravnih travišč (tip 1 HNV), b) mozaik nizko intenzivnih kmetijskih habitatov (tip $2 \mathrm{HNV}$ ).

Nevertheless, recent changes in agricultural practices, linked to a large extent with Romania's accession to the EU in 2007, threaten these valuable habitats (Page et al. 2012). The loss of HNV farmland in itself, either through degradation (i.e. overgrazing or abandonment and scrub encroachment) or land use change, can be seen as the symptom that undesirable. However, the underlying problems in the Târnava Mare region are the various social and economic drivers that are continuing to make low-intensity, biodiversity-friendly farming socially and economically unrewarding and undesirable. The aim of this commentary is to reflect, from the perspective of an NGO, on the experiences in the Târnava Mare region with the implementation of multiple overlapping instruments counteracting both symptoms and problems of HNV farmland loss. Although this region is unique in many ways, it faces similar challenges to other open semi-natural landscapes in Eastern Europe, such as aging populations, falling prices for agricultural products and pressure to intensify agriculture (Keenleyside et al. 2007).

\section{OVERVIEW OF MEASURES CONTRIBUTING TO THE SUPPORT OF HNV FARMLAND IN THE TÂRNAVA MARE REGION}

The Târnava Mare region has been the focus of a number of different activities related to the conservation of its semi-natural landscapes, ranging from legal protection (e.g. Natura 2000) through compensatory payments (e.g. agri-environment measures under the Common Agricultural Policy), public funding of practical interventions (e.g. EU LIFE funding), rural development measures (e.g. restructuring of semi-subsistence farms) to scientific research (e.g. within the context of the publicly funded projects, as well as many other independent research projects). Examples of just a few of the activities that directly or indirectly support the biodiversity of HNV farmland and are, or have been, applied in the region in recent years are given in Table 2. Most of these activities are interlinked in some way, at the very least due to the spatial overlap in their application. Below, we will describe three of the most important conservation instruments - Natura 2000, agri-environment and public funding - before discussing the positive and negative influences that they have had in combination in addressing different aspects of the conservation of HNV farmland in the Târnava Mare region.

\subsection{Agri-environment (-Climate) SCHEMES (AES)}

AES provide compensatory payments for prescribed environmentally friendly farming practices, and are largest source of funding for biodiversity conservation in the EU, with approximately $€ 27.8$ billion being spent on AES support over the period 2007-2012 (ENRD 2013). 70\% of eligible holdings in the Târnava Mare region have AES agreements (unpublished data for 2012 
Table 2: Selected examples of recent activities directly or indirectly contributing to the conservation of semi-natural farmed landscapes in the Târnava Mare region.

Tabela 2: Izbrani primeri trenutnih dejavnosti, ki neposredno ali posredno prispevajo k ohranjanju pol naravne kmetijske krajine v regiji Târnava Mare.

\begin{tabular}{|c|c|c|}
\hline Name & Description & Reference \\
\hline AES & $\begin{array}{l}\text { Agri-environment(-climate) schemes: compensatory payments for conservation } \\
\text { actions implemented under the EU Common Agricultural Policy }\end{array}$ & See Table 3 \\
\hline \multirow{2}{*}{$\begin{array}{l}\text { Butterfly } \\
\text { monitoring }\end{array}$} & National volunteer initiative & Loos \& Kirkland (2014) \\
\hline & $\begin{array}{l}\text { Monitoring butterfly populations in Romania since } 2012 \text { as part of a European } \\
\text { network of butterfly monitoring (van Swaay and Warren 2012) }\end{array}$ & \\
\hline \multirow{2}{*}{$\begin{array}{l}\text { LIFE- } \\
\text { Aquila } \\
\text { pomarina }\end{array}$} & EU-LIFE + public funding & http://pomarina.ro/ \\
\hline & $\begin{array}{l}\text { "Conservation of Aquila pomarina in Romania" funded between } 2010 \text { and } 2013 . \\
\text { Collaboration between the Regional Environmental Protection Agency Sibiu, } \\
\text { Milvus Group and the Romanian Ornithological Society. }\end{array}$ & \\
\hline \multirow{2}{*}{$\begin{array}{l}\text { LIFE- } \\
\text { STIPA }\end{array}$} & EU-LIFE + public funding & Akeroyd et al. (2013) \\
\hline & $\begin{array}{l}\text { "STIPA - Saving Transylvania's Important Pastoral Ecosystems" project funded } \\
\text { between 2010-2013. }\end{array}$ & \\
\hline \multirow[t]{2}{*}{$\begin{array}{l}\text { Natura } \\
2000\end{array}$} & $\begin{array}{l}\text { Legal protection through the EU Habitats and Birds Directives }(92 / 43 / E E C \text { and } \\
2009 / 147 / E C)\end{array}$ & http://natura2000.eea. \\
\hline & $\begin{array}{l}\text { "ROSCI0227 Sighişoara-Târnava Mare", } 85,815 \text { ha designated as SCI (Site of } \\
\text { Community Importance) in 2008; "ROSPA0099 Podişul Hârtibaciului" 237,514 } \\
\text { ha designated as SPA (Special Protection Area) in } 2006\end{array}$ & $\begin{array}{l}\text { aspx?site=ROSC10227 } \\
\text { http://natura2000.eea. } \\
\text { europa.eu/Natura2000/SDF. } \\
\text { aspx?site=ROSPA0099 }\end{array}$ \\
\hline \multirow{2}{*}{$\begin{array}{l}\text { Protected } \\
\text { areas }\end{array}$} & Nature reserves protected under national law & Öllerer (2012) \\
\hline & Breite wood pasture reserve (70ha), Downy oak reserve (11.9 ha). & \\
\hline \multirow[t]{2}{*}{$\begin{array}{l}\text { RDP } \\
\text { measures }\end{array}$} & $\begin{array}{l}\text { National grants and subsidies through the rural development programme in } \\
\text { compliance with the EU Common Agricultural Policy (other than AES) }\end{array}$ & MARD (2007) \\
\hline & $\begin{array}{l}\text { e.g. Measure 141: Supporting semi-subsistence farms, Measure 142: Setting up } \\
\text { producer groups }\end{array}$ & \\
\hline \multirow{2}{*}{$\begin{array}{l}\text { Swiss } \\
\text { Civil } \\
\text { Society } \\
\text { Fund }\end{array}$} & Public funding from the Swiss government to $\mathrm{NGOs}$ & \multirow{2}{*}{$\begin{array}{l}\text { http://www.fundatia-adept. } \\
\text { org/?content=news } \\
\text { detail\&news_id }=7 \overline{3}\end{array}$} \\
\hline & $\begin{array}{l}\text { "Rural Development and High Nature Value Farmland in Romania" project } \\
\text { funded between 2013-2016. Collaboration between AGRIDEA }(\mathrm{CH}) \text {, Fundatia } \\
\text { ADEPT Transilvania, WWF Romania and ProPark (RO). }\end{array}$ & \\
\hline
\end{tabular}

from the Romanian Payments Agency), which is approximately seven times higher than in the neighbouring communes. This is due to intensive awareness-raising and advisory activities, but also affected by the area being a test region for pilot schemes in 2006, which formed the basis for the development of the AES implemented in the 2007-2013 programming period. AES and direct payments now form a considerable proportion of agricultural income: combining these options for grassland can yield up to around $280 €$ / ha/year, which is equivalent to an average monthly salary in the region.

'Broad and shallow' measures such as scrub clearance and minimum stocking rates linked to both AES and direct payments have made a visible difference and improved the condition of large areas of land that was suffering from scrub encroachment (Akeroyd et al. 2013). However, knowledge among farmers of the exact rules and requirements is generally quite low, and there is the danger that people are clearing too much, because they are afraid of the sanctions imposed after monitoring. There is also the danger that widespread measures have a homogenizing effect on the natural heterogeneity of the farmland, for example due to clearance of scrub (as has been shown in Bulgaria: Nikolov et al. 2011) or the synchronisation of mowing dates (Cizek et al. 2011, Dahlström et al. 2013). Feedback to the Ministry of Agriculture and Rural Development from scientists and NGOs has helped to improve 
the design of schemes (e.g. creating higher levels of payment for meadow than pasture to reduce the loss of distinctive meadow plant communities, as well as including traditional orchards in the grassland scheme) as well as the selection of schemes (e.g. the development of measures tailored to birds and butterflies of conservation concern) during the programming period (Table 3). AES have been successful in tackling some of the symptoms of loss of HNV farmland by subsidising low-intensity farming practices, and now most small-scale farming in the region is dependent on payments for its continuation. There is, however, no evidence that it would continue sustainably should the payments cease (Sutcliffe et al. 2013).

\subsection{Natura 2000}

In December 2008, the Târnava Mare SCI (Site of Community Importance) was established. Together with the larger, overlapping SPA (Special Protection Area, under the Birds Directive), this was one of the first Natura 2000 sites in Romania to target semi-natural farmed landscapes rather than "wild" reserves. As such, it has played a role in changing mindsets at the national level about the nature value of farmed landscapes. As an SCI, no payments are yet available for the support of sensitive areas within it, until the management plan and transition to SAC (Special Area of Conservation) have been completed. However, certain planning and land use restrictions are already in place (although in practice these are not strictly enforced).

At the local level, the SCI was not developed with close involvement of local communities, and only around a quarter of people living in and around the SCI have heard of Natura 2000 (Gallup 2011, F. Mikulcak, unpublished data from 2012). There is also ambivalence within the local authorities towards the designation as it is perceived to impose restrictions on economic development without bringing (direct) benefits (Mikulcak et al. 2013). The main benefits of the SCI have therefore been indirect (discussed in more detail in Section 3). By attracting attention, and theoretically resources, to the area, the designation as a Natura 2000 site can to some extent be seen as a problembased solution to the loss of semi-natural habitats through lack of financial viability.

\subsection{Publicly funded Gonservation PROJECTS}

Over the past decade, a number of projects relevant to the support of semi-natural open landscapes have been implemented in the Târnava Mare region, funded by national or international public donors under the administration of NGOs. Such projects generally have a broad aim fitting to the interests of the main funding organisation. These often involve a number of objectives relat-

Table 3: Overview of the preliminary options available as of 2015 as part of the Romanian agri-environmentclimate programme at the national level (sources: MARD 2007, 2014). ${ }^{*}=$ New options in the 2015-2020 rural development plan (compared to the 2007-2013 RDP). $\dagger=$ now with differentiated mowing times for upland and lowland areas.

Tabela 3: Pregled predhodnih možnosti v romunskem kmetijsko-okoljsko-klimatskem programu na nacionalni ravni od leta 2015 (viri: MARD 2007, 2014). ${ }^{*}=$ Nove možnosti v programu razvoja podeželja (v primerjavi s programom RDP 2007-2013). † = zdaj s spremenjenimi obdobji za košnjo za višinska in nižinska območja.

\begin{tabular}{|c|c|}
\hline Option & Estimated payment $(€ /$ ha/year $)$ \\
\hline$\dagger 1$. HNV grassland & 139 \\
\hline \multicolumn{2}{|l|}{ 2. Traditional agricultural practices } \\
\hline 2.1 Manual cutting of hay-meadows and orchards & 107 \\
\hline *2.2 Use of low-impact machinery on hay-meadows and orchards & 21 \\
\hline \multicolumn{2}{|l|}{ 3. Grasslands important for birds } \\
\hline 3.1 Crex crex & 244 \\
\hline 3.2 Lanius minor and Falco vespertinus & 171 \\
\hline 4. Green cover crops & 126 \\
\hline *5. Adaptation to climate change effects & 126 \\
\hline *6. Grasslands important for butterflies (Maculinea sp.) & 263 \\
\hline *7. Arable land important for the red-breasted goose (Branta ruficollis) & 288 \\
\hline
\end{tabular}


ed to the overall conservation goal, and as such can finance multiple types of activities addressing different facets of both the identified problem and its symptoms. For example, the many activities carried out within the LIFE-STIPA project (see Table 3) have included physical clearance of excess scrub from 350 ha of grassland to restore open pasture and meadow, but also school visits helped to raise awareness of the next generation of land managers about the importance of the biodiversity of open habitats. In contrast, other projects have targeted mainly the underlying problems, for example within a Swiss-funded project markets were developed for products from $\mathrm{HNV}$ farmland in the area, helping to increase profits and thus viability of low-intensity farming. These projects also play a role in stimulating collaboration and networking between several organisations to carry out the activities, including national and regional nature conservation NGOs, international NGOs and government agencies (such as the Swiss-funded project and the LIFEAquila pomarina project; see Table 3).

\section{INDIRECT POSITIVE EFFECTS AND SYNERGIES}

The spatial overlap of these and other conservation initiatives appear to have had a number of positive effects on each other, and we assume (although it is very difficult to determine for certain) that a certain degree of the success of each individual initiative has been due to the synergies with other initiatives. For example, information activities initiated by publically funded projects may be to some extent responsible for the much higher local participation rate in AES than that in neighbouring regions. The Natura 2000 designation of the area has undoubtedly increased the likelihood of attracting funding (such as EU LIFE projects) as well as independent research focussed on the ecology and natural history of the area. This research has helped to accumulate a relatively detailed scientific picture of the region, contributing to the (ongoing) development of management plans for the Natura 2000 region. Funded projects have often provided the means to develop pilot projects, such as trialling single axle mowers within the LIFE project, which provide the basis to lobby for policy changes such the modification of the Romanian agri-environment programme to include payments for low impact mowing machines (Table 3). Publicly funded projects also provide a platform for the capacity building and networking of NGOs both nationally and internationally, allowing them to gather new ideas and influence national and regional policy. Both the Ministry of Environment and Climate Change and the Ministry of Agriculture and Rural Development in Romania are underfunded and lacking in capacity to fulfil their roles, as well as lacking in coordination between them (Wegener et al. 2011, see also Prazan \& Theesfeld 2014 for a discussion of as similar situation in Poland), making the role of NGOs to fill in the gaps particularly important.

\section{INDIRECT NEGATIVE EFFECTS AND RESILIENCE}

In contrast to the above examples, the application of several of the conservation-related initiatives has also had indirect negative or neutral effects. However, in these cases, the overlap of activities or actors may act to compensate for the failure of some instruments. For example, there is no standardised monitoring built in to the national agri-environment programme or the management of the Târnava Mare SCI to assess the impacts on biodiversity. Monitoring plays a key role in the success of any intervention, yet only few countries have a monitoring system in place for their AES (see e.g. Tucker et al. 2003). In Târnava Mare, this gap is to a small extent filled by citizen science in the form of a new national volunteer butterfly monitoring scheme (see Table 2). Another example is that the AES payment from 2007-2014 was the same for both pastures and meadows. This led to the situation where many hay-meadows were being converted into less labour-intensive pastures with widespread overgrazing by sheep, threatening the unique speciesrich meadow communities. This loss of meadow has been partially mitigated by the provision of single axle mowers through the LIFE-STIPA project, which can be rented to lower the cost of mowing. Finally, several measures in the Romanian rural development plan to support $\mathrm{HNV}$ farming communities, including measure 142 "setting up producer groups" (see Table 2) had extremely low uptake, as it was poorly designed to meet the needs of small-scale farmers (Luca \& Toderiță 2012). Instead, small producers in the region have been helped to market products such 
as cheeses, jams, juices and pickles from $\mathrm{HNV}$ farmland through initiatives like the Swiss contribution project (see Table 2).

\section{CONCLUDING REMARKS}

Conservation of HNV landscapes is a priority throughout Europe, but particularly so in Southeastern European countries such as Romania, which have some of the largest areas of low-intensity farmland in Europe but also some of the strongest drivers of intensification and abandonment (Sutcliffe et al. 2015). The maintenance of these semi-natural open areas is becoming increasingly decoupled from production, and more reliant on the financial and legal instruments of support for the biodiversity and other public goods that they provide. In the HNV farmland of the Târnava Mare region in Southern Transylvania, a number of different types of conservation initiatives have been implemented in the last decade, only a few of which have been discussed here. In considering our experience with the overlap of these initiatives, we draw several conclusions, which are likely to be relevant not only for this region but also for many other farmed, semi-natural areas.

First, as man-made habitats, addressing the degradation of semi-natural farmland requires approaches that tackle both the symptoms and the underlying problems with a range of instruments. Addressing only the symptom, for example by stipulating scrub clearance in return for compensatory payments, may lead to excessive loss of shrubs, because either the rules were too strict or misunderstood. However, only few instruments or initiatives provide cross-cutting funding to integrate both social and ecological approaches.

Second, activity attracts activity, and we should not underestimate the importance of multiple overlapping nature conservation tools but rather seek to use the synergies between them. Nevertheless, the complex positive and negative interactions between these instruments in their goal of supporting HNV farmland are rarely studied holistically.

Third, HNV landscapes and the communities that manage them are not only heterogeneous in space, but also constantly change over time. It is therefore also important to have available a variety of strategies, which provide a degree of resil- ience in approaches. This reflects the resilience of species-rich habitats: if one instrument or activity fails, then farmers or conservation practitioners can fall back on another.

Finally, sustainable nature conservation in the Târnava Mare region and other HNV landscapes requires economic development and change to promote living farming communities, rather than the "preservation" of the countryside (Fischer et al. 2012). The valuing of biodiversity not just by policy but also by local people is critical to achieve this. Not all HNV areas benefit from so many conservation instruments (in fact, some are not even eligible for the most basic agricultural subsidy: see e.g. Keenleyside et al. 2014), or have the institutions and actors to drive their implementation. One promising development is therefore the growing evidence of the strong positive effect of farmland biodiversity on ecosystem functioning and services (e.g. on biomass production in grassland: Bullock et al. 2001, 2007, Weigelt et al. 2009). Such evidence of tangible benefits is another important string in the bow of conservation approaches, and has much potential to justify continued farming of this important habitat.

\section{ACKNOWLEDGEMENTS}

We gratefully acknowledge the support of Fundația Orange, the Darwin Initiative, Innovation Norway, EU-LIFE+, Fauna and Flora International, and POS-Mediu, as well as the many individuals who contributed to the success of the projects mentioned. Thanks also go to R. Oppermann and one anonymous reviewer for their helpful comments on the manuscript, as well as to F. Mikulcak for providing data.

\section{REFERENCES}

Akeroyd, J. R. \& Bădărău S. 2012: Indicator plants of the High Nature Value dry grasslands of Transylvania. Fundatia ADEPT Transilvania, Saschiz, 16 pp.

Akeroyd, J. R. \& Page N. 2011: Conservation of High Nature Value (HNV) grassland in a farmed landscape in Transylvania, Romania. Contributii Botanice 46: 57-71.

Akeroyd, J. R., Sutcliffe L. M. E., Popa R. \& Page N. 2013: The LIFE project STIPA: Saving Transylvania's important pastoral agro-eco- 
systems (Romania). In: Baumbach, H. \& Pfützenreuter, S. (eds.):Steppenlebensräume Europas - Gefährdung, Erhaltungsmassnahmen und Schutz. TMLFUN, Erfurt, pp. 341-350.

Bullock, J. M., Pywell, R. F., Burke, M. J. W. \& Walker, K. J. 2001: Restoration of biodiversity enhances agricultural production. Ecology Letters 4: 185-189.

Bullock, J. M., Pywell, R. F. \& Walker, K. J. 2007: Long-term enhancement of agricultural production by restoration of biodiversity. Journal of Applied Ecology 44: 6-12.

Cizek, O., Zamecnik, J., Tropek, R., Kocarek, P. \& Konvicka, M. 2011: Diversification of mowing regime increases arthropods diversity in species-poor cultural hay meadows. Journal of Insect Conservation 16: 215-226. DOI: 10.1007/s10841-011-9407-6.

Dahlström, A., Iuga, A.-M. \& Lennartsson, T. 2013: Managing biodiversity rich hay meadows in the EU: a comparison of Swedish and Romanian grasslands. Environmental Conservation 40: 194-205. DOI: $10.1017 /$ S0376892912000458.

ENRD 2013: State of the Total Public and EAFRD expenditure per measure. European Network for Rural Development, Brussels. URL: http://enrd.ec.europa.eu/app_templates/ enrd_assets/pdf/monitoring_indicators/financial_and_physical_indicators/rdp/b_financial-expenditure-2013_a_eu27.pdf.

Fischer, J., Hartel, T. \& Kuemmerle, T. 2012: Conservation policy in traditional farming landscapes. Conservation Letters 5: 167-175. DOI: $10.1111 / \mathrm{j} .1755-263 X .2012 .00227 . x$.

Gallup 2011: Raport de cercetare: Evaluarea nivelului de informare şi înțelegere al populației privind Rețeaua Ecologică Natura 2000 [Survey: An evaluation of the level of information and understanding in the population regarding the Natura 2000 ecological network]. WWF Danube Carpathian Programme, Bucharest, $82 \mathrm{pp}$.

Hartel, T. \& Moga, C. I. 2010: Manual de bună practică în managementul habitatelor de pajişte cu arbori seculari [Good-practice guidebook for the management of wood-pasture habitats with veteran trees]. Mihai Eminescu Trust, Sighişoara, $100 \mathrm{pp}$.

Hartel, T., Nemes, S., Öllerer, K., Cogălniceanu, D., Moga, C. I. \& Arntzen, J. W. 2010a: Using connectivity metrics and niche modelling to explore the occurrence of the northern crested newt Triturus cristatus (Amphibia, Caudata) in a traditionally managed landscape. Environmental Conservation 37: 195-200. DOI: 10.1017/ S037689291000055X.

Hartel, T., Schweiger, O., Öllerer, K., Cogălniceanu, D. \& Arntzen, J. W. 2010b: Amphibian distribution in a traditionally managed rural landscape of Eastern Europe: Probing the effect of landscape composition. Biological Conservation 143: 1118-1124. DOI: 10.1016/j. biocon.2010.02.006.

Hochkirch, A., Schmitt, T., Beninde, J., Hiery, M., Kinitz, T., Kirschey, J., Matenaar, D., Rohde, K., Stoefen, A., Wagner, N., Zink, A., Lötters, S., Veith, M. \& Proelss, A. 2013: Europe Needs a New Vision for a Natura 2020 Network. Conservation Letters 6: 462-467. DOI: $10.1111 /$ conl.12006.

Iojă, C. I., Pătroescu, M., Rozylowicz, L., Popescu, V. D., Verghelet,, M., Zotta, M. I. \& Felciuc, M. 2010: The efficacy of Romania's protected areas network in conserving biodiversity. Biological Conservation 143: 2468-2476. DOI: 10.1016/j.biocon.2010.06.013.

Keenleyside, C., Arblaster, K., Baldock, D., van Dijk, G. \& Szemplinska, M. 2007: The relationship between the CAP and biodiversity. DLG Government Service for Land and Water Management, Utrecht, 66 pp..

Keenleyside, C., Beaufoy, G., Tucker, G. M. \& Jones, G. 2014: High Nature Value farming throughout EU-27 and its financial support under the CAP. Institute for European Environmental Policy, London, 172 pp..

Kleijn, D., Baquero, R. A., Clough, Y., Díaz, M., De Esteban, J., Fernández, F., Gabriel, D., Herzog, F., Holzschuh, A., Jöhl, R., Knop, E., Kruess, A., Marshall, E. J. P., Steffan-Dewenter, I., Tscharntke, T., Verhulst, J., West, T. M. \& Yela, J. L. 2006: Mixed biodiversity benefits of agri-environment schemes in five European countries. Ecology Letters 9: 243-254. DOI: 10.1111/j.1461-0248.2005.00869.x.

Loos, J., Dorresteijn, I., Hanspach, J., Fust, P., Rakosy, L. \& Fischer, J. 2014: Low-intensity agricultural landscapes in transylvania support high butterfly diversity: implications for conservation. PLoS One 9: e103256.

Loos, J., \& Kirkland, P. 2014: Establishing butterfly monitoring in Romania. Oedippus 29: 32-38.

Luca, L., \& Toderiță, A. 2012: Why isn't agricultural association attractive? Romanian Center for European Policies, Bucharest, 17 pp. 
MARD 2007: National Rural Development Programme 2007-2013. Ministry of Agriculture and Rural Development: Government of Romania, Bucharest, 812 pp.

MARD 2014: National Rural Development Programme for the 2014-2020 period. Official version 1 ( $1^{\text {st }}$ July 2014). Ministry of Agriculture and Rural Development: Government of Romania, Bucharest, 665 pp.

Mikulcak, F., Newig, J., Milcu, A. I., Hartel, T. \& Fischer, J. 2013: Integrating rural development and biodiversity conservation in Central Romania. Environmental Conservation 40: 129-137. DOI: 10.1017/S0376892912000392.

Nikolov, S. C., Demerdzhiev, D. A., Popgeorgiev, G. S. \& Plachiyski, D. G. 2011: Bird community patterns in sub-Mediterranean pastures: the effects of shrub cover and grazing intensity. Animal Biodiversity and Conservation 34: 11-21.

Öllerer, K. 2012: The flora of the Breite wood pasture (Sighişoara, Romania). Brukenthal Acta Musei 7: 589-604.

Oppermann, R., Beaufoy, G. \& Jones, G. (eds.) 2012: High Nature Value Farming in Europe: 35 European countries - experiences and perspectives. verlag regionalkultur, Ubstadt-Weiher, 544 pp.

Page, N., Popa, R., Huband, S., Balan, A. \& Sutcliffe, L. M. E. 2012: Romania. In: Oppermann, R., Beaufoy, G. \& Jones, G. (eds.): High Nature Value Farming in Europe: $35 \mathrm{Eu}-$ ropean countries - experiences and perspectives. verlag regionalkultur, Ubstadt-Weiher, pp. 346-357.

Paracchini, M. L. \& Oppermann, R. 2012: Public goods and ecosystem services delivered by HNV farmland. In: Oppermann, R., Beaufoy, G. \& Jones, G. (eds.): High Nature Value Farming in Europe: 35 European countries experiences and perspectives. verlag regionalkultur, Ubstadt-Weiher, pp. 446-450.

Paracchini, M. L., Petersen, J.-E., Hoogeveen, Y., Bamps, C., Burfield, I. \& van Swaay, C. 2008: High Nature Value Farmland in Europe. JRC, Luxembourg, 102 pp.

Plieninger, T. \& Bieling, C. 2013: Resilience-based perspectives to guiding High-Nature-Value farmland. Ecology and Society 18(4): Article 20. DOI: $10.5751 / \mathrm{ES}-05877-180420$.

Prazan, J. \& Theesfeld, I. 2014: The role of agrienvironmental contracts in saving biodiversity in the post-socialist Czech Republic. International Journal of the Commons 8: 1-25.
Rákosy, L. 2012: Indicator butterflies and moths of the High Nature Value dry grasslands of Transylvania. Fundația ADEPT Transilvania, Saschiz, 54 pp.

Roellig, M., Dorresteijn, I., von Wehrden, H., Hartel, T. R. \& Fischer, J. 2014: Bear activity in traditional wood-pastures in southern Transylvania, Romania. Ursus 25: 43-52.

Scheele, B. C., Boyd, C. E., Fischer, J., Fletcher, A. W., Hanspach, J. \& Hartel, T. 2014: Identifying core habitat before it's too late: the case of Bombina variegata, an internationally endangered amphibian. Biodiversity and Conservation 23: 775-780. DOI: 10.1007/s10531014-0624-7.

Schmitt, T. \& Rákosy, L. 2007: Changes of traditional agrarian landscapes and their conservation implications: a case study of butterflies in Romania. Diversity and Distributions 13: 855862. DOI: 10.1111/j.1472-4642.2007.00347.x.

Speta, E. \& Rákosy, L. 2010: Wildpflanzen Siebenbürgens. Plöchl, Freistadt, 624 pp.

Stoate, C., Báldi, A., Beja, P., Boatman, N. D., Herzon, I., van Doorn, A., de Snoo, G. R., Rakosy, L. \& Ramwell, C. 2009: Ecological impacts of early 21 st century agricultural change in Europe - A review. Journal of Environmental Management 91: 22-46. DOI: 10.1016/j. jenvman.2009.07.005.

Sutcliffe, L. M. E., Batáry, P., Kormann, U., Báldi, A., Dicks L. V., Herzon, I., Kleijn, D., Tryjanowski, P., Apostolova, I., Arlettaz, R., Aunins, A., Aviron, S., Balezentiene, L., Fischer, C., Halada, L., Hartel, T., Helm, A., Hristov, I., Jelaska, S. V., Kaligarič, M., Kamp, J., Klimek, S., Koorberg, P., Kostiuková, J., Kovács-Hostyánszki, A., Kuemmerle, T., Leuschner, C., Lindborg, R., Loos, J., Maccherini, S., Marja, R., Máthé, O., Paulini, I., Proença, V., Rey-Benayas, J., Sans, F. X., Seifert, C., Stalenga, J., Timaeus, J., Török, P., van Swaay, C., Viik, E. \& Tscharntke, T. (in press): Harnessing the biodiversity value of Central and Eastern European farmland. Diversity and Distributions. DOI: 10.1111/ddi.12288.

Sutcliffe, L. M. E., Paulini, I., Jones, G., Marggraf, R. \& Page, N. 2013: Pastoral commons use in Romania and the role of the Common Agricultural Policy. International Journal of the Commons 7: 58-72.

Tucker, G.M., Petterson, D., Donkin, P., Brockhurst, C., Stephenson, B., Leay, M. \& Crabtree, B. 2003: Review of Agri-Environment 
Schemes - Monitoring Information and R \& D Results. Report for the UK Department for Environment, Food and Rural Affairs, London, $125 \mathrm{pp}$.

Van Swaay, C., \& Warren, M. 2012: Developing butterflies as indicators in Europe: current situation and future options. De Vlinderstichting/Dutch Butterfly Conservation, Wageningen, $24 \mathrm{pp}$.

Wegener, S., Labar, K., Petrick, M., Marquardt, D., Theesfeld, I. \& Buchenrieder, G. 2011: Administering the Common Agricultural Policy in Bulgaria and Romania: obstacles to accountability and administrative capacity. International Review of Administrative Sciences 77: 583-608.
Weigelt, A., Weisser, W. W., Buchmann, N. \& Scherer-Lorenzen, M. 2009: Biodiversity for multifunctional grasslands: equal productivity in high-diversity low-input and low-diversity high-input systems. Biogeosciences 6: 16951706.

Wilson, J. B., Peet, R. K., Dengler, J. \& Pärtel, M. 2012: Plant species richness: the world records. Journal of Vegetation Science 23: 796802.

Received: 15 May 2014 Accepted: 22 February 2015

Co-ordinating Editor: Jasmin Mantilla-Contreras 